УДК 373.3.015.31:796

DOI:

Тетяна Надім'янова, кандидат педагогічних наук, дочент кафедри педагогіки та методики початкової освіти Дрогобицького державного педагогічного університету імені Івана Франка

Анна Чепелюк, кандидат педагогічних наук,

старший викладач кафедри спортивних дисциплін та туризму Дрогобицького державного педагогічного університету імені Івана Франка

\title{
ІННОВАЦІЙНІ ПІДХОДИ У ФІЗИЧНОМУ ВИХОВАННІ УЧНІВ ПОЧАТКОВОї ШКОЛИ
}

У статті з'ясовано сутність інновачійних підходів у системі фізичного виховання учнів початковоі школи, яка має великі можливості для розв'язання завдань здоров'язбереження, розвитку творчоі особистості, самореалізації, самовдосконалення, формування інтересу до фізичної культури та спорту, активної рухової діяльності. Розглянуто зміст навчальних програм з фізичної культури, що мають інноваційну складову. Проаналізовано авторські методики вітчизняних науковців, які в організачії фізичного виховання одним із шляхів його вдосконалення вбачають інновачійні технології, щзо сприятимуть покращенню здоров'я учнів різновікових груп, зменшуватимуть втомлюваність, підвищуватимуть продуктивність розумової праці.

Ключові слова: Нова украӥнська школа; інновачійна діяльність; інновачійний підхід; фізичне виховання; фізкультурно-оздоровча робота; молодший школяр.

Jim. 10.

Tetyana Nadimyanova, Ph.D.(Pedagogy), Associate Professor of the Pedagogy and Methodology of Elementary Education Department Drohobych Ivan Franko State Pedagogical University Anna Chepelyuk, Ph.D.(Pedagogy), Senior Lector of the Sports Disciplines and Tourism Department Drohobych Ivan Franko State Pedagogical University

\section{INNOVATIVE APPROACHES IN THE PHYSICAL EDUCATION OF ELEMENTARY SCHOOL STUDENTS}

The article outlines the essence of innovative approaches in the system of physical education of elementary school students which have great opportunities for solving the issues of health preservation, development of creative personality, self-realization, self-improvement, formation of interest towards physical culture and sports, active motor activity. The system of physical education, the versatility of which is not only to improve the health of the growing generation, but also to unite spiritual, moral, intellectual, emotional, aesthetic wealth of the individual, and should be aimed at innovative educational activities. The content of physical education curricula that contain an innovative components were reviewed. The author's methodology of Ukrainian scientists who consider innovative approaches of the organization of physical education as one of the ways of its improvement were analyzed. Those were the approaches that are aimed to improve student's health of different age groups, reduce fatigue, and increase productivity of brain work. The modern system of physical education requires active transformations as a result of new trends introduction, which depend on the development and substantiation of innovative technologies, mechanisms and their implementation to the secondary schools programs. Innovative approach to the system of physical education, which is conducted in elementary school, will be considered realized, in case of reduction of the rates of students morbidity and improvement of their health will be achieved; raising the level of physical and mental performance; development of creative abilities, inclinations and desires of each child; stable motivation for a healthy lifestyle and motor activity. Innovative activities require a creative, responsible approach, with non-standard scientific thinking of a teacher, who, in the conditions of the New Ukrainian school, will solve educational, educational, recreational tasks.

Keywords: New Ukrainian school; an innovative activity; an innovative approach; physical education; physical culture and health work; junior students.

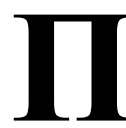

остановка проблеми. Сьогочасне століття означене напруженим пошуком нового світорозуміння, нових перспектив розвитку компетентної особистості, спроможної створити свій життєвий проект, відповідально ставитися до життя, упевнено приймати історичний виклик тисячоліття. Тому однією з найголовніших проблем, пов'язаних 3 розбудовою демократичної української держави, $€$ проблема освітня, у центрі якої стоїть дитина 3 


\section{ІННОВАЦІЙНІ ПІДХОДИ У ФІЗИЧНОМУ ВИХОВАННІ УЧНІВ ПОЧАТКОВОЇ ШКОЛИ}

ії природними задатками, інтересами, уподобаннями. В умовах реалій сучасного життя одним із актуальних питань постало упровадження концепції “Нової української школи” (НУШ), завданнями якої $є$ :

- перехід від знаннєвої парадигми до компетентнісної;

- надання свободи у діяльності вчителя;

- розвиток зацікавлення і підвищення мотивації учнів у навчанні;

- повага до гідності учня, створення умов для саморозвитку і самовираження учнів [6].

Найважливішим і найціннішим досягненням у галузі освіти XXI століття має стати зміцнення і покращення здоров'я учнівської молоді. За даними Міністерства охорони здоров'я, за останнє десятиліття серед дитячого населення істотно зросла частота хронічних захворювань (у 1,5 - 3 рази), які призводять до інвалідності. Кількість хронічно хворих дітей за роки навчання у школі збільшується у 2,5 рази; $36,4 \%$ учнів загальноосвітніх шкіл мають дуже низький рівень фізичної підготовленості, 33,5\% - нижче середнього, 22,6\% - середній, 6,7\% - вище середнього, і лише $0,8 \%$ - високий $[3,20]$. Особлива роль у комплексі факторів, що впливають на формування здоров'я дітей (соціально-економічні умови, навколишнє середовище, мотивація до здорового способу життя, медико-санітарна допомога тощо) належить руховому режиму, режиму дня, умовам навчання й виховання. Завдання з покращення здоров'я школярів має вирішуватися через організацію процесу фізичного виховання. Система освіти потребує активних перетворень процесів навчання й виховання дітей та молоді, тому очевидною стає необхідність оновлення сучасної системи фізичного виховання, яке спрямоване на нову освітню діяльність, тенденції до збереження здоров'я й розвиток індивідуальності зростаючої особистості.

Аналіз основних положень і публікацій. Питання інноваційних підходів в освітньому процесі з фізичного виховання були предметом наукових пошуків багатьох вітчизняних дослідників: Р. Богайчук О. Вацеби, О. Ващенко, Е. Вільчковського, О. Власюк, Н. Денисенко, В. Дробинського, Г. Ільницької, М. Єфименка, Т. Круцевич, Н. Москаленко, О. Савченко, I. Степанової, М. Папуші, С. Приступи, І. Турчик, О. Шиян, Р. Шияна, А. Цьося та ін. Науковці розглядають інновації у фізичному вихованні як результат творчого пошуку, нестандартних рішень багатьох педагогічних проблем, оригінальних різноманітних ініціатив і нововведень, що позитивно впливають на особистість, а від так, й на продукти інноваційної освітньої діяльності.

Попри значний внесок науковців у розробку інноваційних підходів у фізичному вихованні учнівської молоді, питання особистісного розвитку школяра в умовах запровадження НУШ, а також освітньо-виховних закладів нового типу (ліцеїв, гімназій, коледжів, колегіумів, авторських шкіл тощо) перебуває у тісному зв'язку із створенням максимально сприятливих умов для розвитку фізичних, духовних та моральних якостей учнів різного віку. Фізичне виховання має надзвичайно великі можливості для розв'язання цих завдань.

Мета статті. Розглянути особливості запровадження змісту інноваційної діяльності як процесу зміни й створення нового в організації фізичного виховання учнів початкової школи.

Виклад основного матеріалу дослідження. Модернізація освітнього процесу в Україні (перехід навчальних закладів на новий зміст, структуру й термін навчання), інформаційні перенавантаження висувають високі вимоги до діяльності школярів різного віку, починаючи з початкової ланки. Оскільки пріоритетним напрямом державної політики у сфері освіти проголошено особистісноорієнтовану іï модель, призначення якої розширення можливостей компетентного вибору дитиною життєвого шляху та її саморозвиток, то головними в оцінці ефективності виховання й навчання мають стати критерії благополуччя й розвитку дитини як особистості. На жаль, доводиться констатувати, що кожних чотири роки в Україні проводяться освітні реформи. Підвалини цього негативного явища криються в нерозумінні сутності сучасних цивілізаційних змін, нездатності розглядати завдання модернізації освіти в контексті підготовки людини до життя у третьому тисячолітті, яке знаменує собою інноваційні процеси у багатьох галузях - науці, освіті, медицині тощо. Модернізація системи освіти сьогодні пов'язується насамперед із введенням в освітнє середовище інноваційних концепцій, в основу яких покладені цілісні моделі освітньовиховного процесу, засновані на діалектичній єдності методології та засобів їх здійснення, тобто такі, які не лише на рівні ідей, а й на рівні інтерактивних технологій втілюють ідею гуманізації як щодо системи освіти в цілому, так і стосовно конкретних аспектів освітньо-виховного процесу [7, 15]. Для підвищення ефективності цього процесу необхідно шукати нові шляхи удосконалення й системи фізичного виховання, багатогранність якого полягає не лише у покращенні здоров'я зростаючого покоління, а й єдності духовного, морального, інтелектуального, 
емоційного, естетичного тощо багатства особистості. При цьому молодший шкільний вік, у якому відбувається орієнтація на здоровий спосіб життя, виступає основним періодом набуття соціального досвіду, а правильне фізичне виховання у шкільному віці є не тільки необхідною умовою усебічного гармонійного розвитку особистості учня, а й дієвим фактором підвищення його розумової працездатності. Система фізичного виховання має великі можливості для розв'язання завдань творчої особистості засобами фізичної культури, яка у загальноосвітніх навчальних закладах, зокрема, початкової ланки, проводиться відповідно до освітньої програми. Метою навчання фізичної культури в початковій школі є: усебічний фізичний розвиток дітей засобами ігрової і фізкультурної діяльності, формування основних фізкультурних компетентностей, ціннісного ставлення до свого здоров'я, спорту, фізкультурно-оздоровчих занять, виховання фізично здорових громадян. Тому запровадження інноваційних підходів до змісту занять потребує вирішення широкого кола теоретичних й практичних питань.

Інноваційна (від лат. innovatio - оновлення, зміна) діяльність $є$ досить складною, специфічною й потребує особливих знань, навичок, здібностей. Впровадження інновацій неможливе без педагога-дослідника, який володіє системним мисленням, розвиненою здатністю до творчості, сформованою й усвідомленою готовністю до інновацій $[2,29]$. Інноваційна діяльність у фізичному вихованні не може існувати без особистісно-орієнтованої освіти, мета якої полягає у підтриманні й розвиткові у дитини найкращих людських якостей, формуванні механізмів самореалізації, саморозвитку, самовиховання, достатніх для становлення творчої особистості, взаємодії з людьми та оточуючим середовищем. Ці засадничі ідеї лягли в основу концепції Нової української школи та розробки нового Державного стандарту початкової загальної освіти, що базується на таких принципах:

1. Презумпція талановитості дитини. Забезпечення рівного доступу до освіти, заборона будь-яких форм дискримінації. Не допускатиметься відокремлення дітей на підставі попереднього відбору на індивідуальному, груповому та інституційному рівнях.

2. Цінність дитинства. Відповідність освітніх вимог віковим особливостям дитини, визнання прав дитини на навчання через діяльність, зокрема гру.

3. Радість пізнання. Організація пізнавального процесу, яка приноситиме радість дитині, обмеження обсягу домашніх завдань для збільшення часу на рухову активність і творчість дитини. Широке використання в освітньому процесі дослідницької та проектної діяльності.

4. Розвиток особистості. Замість "навченої безпорадності” - плекання самостійності та незалежного мислення. Підтримка з боку вчителя / вчительки розвиватиме у дітей самоповагу та впевненість у собі.

5. Здоров'я. Формування здорового способу життя і створення умов для фізичного й психоемоційного розвитку, що надзвичайно важливо для дітей молодшого шкільного віку.

6. Безпека. Створення атмосфери довіри i взаємоповаги. Перетворення школи на безпечне місце, де немає насильства і цькування [5].

Керуючись цими принципами, експертами Міністерства освіти і науки України були розроблені “Типові освітні програми початкової освіти” $з$ усіх навчальних предметів, що вивчаються у початковій школі. Фізичному вихованню, яке реалізується засобами фізичної культури, відведено належне місце. Розуміння змісту занять особистісно-орієнтованою фізичною культурою дає можливість учителеві цілеспрямовано керувати процесом оволодіння знаннями, вміннями й навичками школяра, тобто процесом його поступового самовдосконалення. Програма з фізичної культури для учнів початкової школи авторами якої є педагоги, науковці під керівництвом Р. Шияна [10], складається з макроі мікроциклів. Навчальний період, що поділений на тижні, має три змістові лінії: "Базова рухова активність”, “Ігрова та змагальна діяльність”, “Турбота про стан здоров'я та безпеку”. Урок має теоретичну і практичну складову. Відповідно до програми конкретного класу, учні знайомляться з основними поняттями, що є базовими у фізичній культурі, формують рухові уміння й навички, набувають фізичні якості. Так, до прикладу, учні першого класу знайомляться із поняттям “фізична культура” яка $є$ сукупністю різноманітних фізичних вправ, спрямованих на зміцнення здоров'я, отримують знання з актуальних питань: для чого потрібно дотримуватись режиму дня, правил особистої гігієни, з якою метою і для чого треба проводити фізкультурні хвилинки, чим може зашкодити малорухомий спосіб життя тощо. Практична частина містить загальнорозвивальні та організовуючі вправи, які представляють комплекси ранкової гігієнічної гімнастики, комплекси для формування правильної постави та профілактики плоскостопості, вправи без предметів на місці. Особливе місце відводиться рухливим іграм. Особливим видом рухливих ігор 
є ігри з інтелектуальним навантаженням, які у комплексі поєднують завдання фізичного та інтелектуального розвитку [1].

Такі рухливі ігри можна проводити на заняттях 3 різних розділів програми, і в повсякденному житті. Їх мета: активізація, закріплення, узагальнення набутих знань, вмінь та навичок, зміцнення фізичного розвитку дітей.

Наведемо приклади рухливих ігор 3 інтелектуальним навантаженням, спрямованих одночасно на фізичний розвиток учнів першого класу й краще засвоєння ними грамоти, розвитку мовлення:

Гра "Хустинонька"

Діти утворюють круг, узявшись за руки. Учень iз хустинкою в руках - у колі. Починаючи промовляти слова, діти йдуть по колу:

“Ой, ти, хустинонько шовкова, ти пливи, пливи по колу!

В руки хто тебе візьме, хай нам відповідь дає"

З останніми словами усі зупиняються. Учень передає хустинку тому, навпроти кого він опинився, й пропонує завдання. Якщо відповідь правильна, учні підстрибують, піднявши руки догори, плескають у долоні. Якщо неправильна роблять нахили вниз. Учитель або учень має виправити неправильну відповідь.

Орієнтовні завдання до гри:

1. Наприклад, утворити іменники зі зменшувальнопестливим суфіксом (сказати лагідно): відро відерце; камінь - камінець, камінчик; хліб - хлібчик; дерево - деревце; береза - берізонька; лялька лялечка; озеро - озерце; качка - качечка тощо.

2. Вжити прислівники з пестливим суфіксом (змінити слово за зразком): гарно - гарненько, гарнесенько; чисто - чистенько, чистесенько тощо.

Гра "Перейди по камінчику через річку”

Кладуть кілька обручів на невеликій відстані один від одного. Діти стоять біля вчителя. Він дає спільне для всіх завдання: “Невеликими кроками, перейти через обруч в обруч, називаючи вголос слово, ділячи його на склади" (у-чень, школя-рик, план-шет, смарт-фон тощо).

Гра "Гарбуз"

Діти утворюють круг. Вчитель (потім хтось із учнів) промовляє слова, а діти котять по колу “гарбуза" (м'яч):

“Їхав дядько Рамазан з гарбузами на базар.

3 воза впали гарбузи, покотилися з гори.

Рамазан став доганяти, а тобі відповідати!”

Учень, біля якої зупинився “гарбуз”, бере його в руки й стає в коло. Виконавши завдання вчителя, віддає “гарбуза" комусь із дітей, і гра повторюється.
Завдання:

1. Наприклад, порівняти предмети; придумати загадку про один із предметів; назвати п’ять слів із заданим звуком; пригадати п'ять назв кольорів; назвати свійських тварин (геометричні фігури; транспортні засоби; шкільне приладдя тощо).

Вчитель повинен пам'ятати, що ігри для дітей (розважальні, інтелектуальні, навчальні, рухові) не просто розвага, чи веселе проведення часу, це складний, багатофункціональний і пізнавальний процес. За допомогою гри дитина виробляє нові форми поведінки і реагування, адаптується до навколишнього середовища, розвивається, дорослішає і вчиться.

Особливу увагу слід надавати організації фізкультурно-оздоровчих прогулянок у різні пори року. Такі інноваційні прогулянки доречно проводити раз на тиждень як позаурочний захід. На таких прогулянках можна використовувати різні оздоровчі технології в поєднанні 3 фізкультурними складовими з метою фізичного розвитку дітей, поліпшення тренованості організму, підвищення його захисних реакцій й опірності шкідливим факторам.

Орієнтовна структура фізкультурно-оздоровчої прогулянки може бути такою: ігровий момент; спостереження у природі; різні види ходьби та біг; загальнорозвивальні вправи; основні рухи та спортивні вправи; рухливі, спортивні, народні ігри; оздоровчі технології (дихальна гімнастика, самомасаж (щічок, носа, долоньок, пальців), пальчикова гімнастика, психогімнастика, різноманітні прийоми загартування тощо); самостійна рухова діяльність дітей.

Прикладом вдалого використання інновацій на уроках фізичної культури можуть бути види спорту, які подобаються учням і викликають у них інтерес, а саме: футзал, скейтбординг, софтбол, флорбол, хортинг (для хлопчиків), різновиди аеробіки - степ-, тай-бо-, шейпінг, стретчинг, роуп-скіппінг (для дівчаток). Принагідно додамо, що кількість учнів, які відвідують дитячі спортивні школи, спортивні секції та клуби зростає щороку.

Заслуговує на увагу й навчальне видання Г. Ільницької, у якому представлена програма 3 фізичної культури для початкової школи. Зміст програми побудовано на основі макроциклу, розрахованого на 12 років навчання, що зумовлює циклічність навчального матеріалу, починаючи 3 дошкільного навчального закладу. У програмі для учнів перших класів акцентовано увагу на вивченні техніки виконання базових вправ та розвитку таких фізичних якостей, як швидкість, спритність, гнучкість, оскільки розвиток 


\section{ІННОВАЦЙНН ПІДХОДИ У ФІЗИЧНОМУ ВИХОВАННІ УЧНІВ ПОЧАТКОВОӤ ШКОЛИ}

переважно цих фізичних якостей у першокласників сприяє здоровому та міцному опорно-руховому апарату та світовідчуттю, що є важливим чинником соціальної адаптації молодших школярів до навчальної діяльності та навколишнього середовища [4].

Прикладом інноваційного підходу у фізичному вихованні дошкільників, учнів молодшого шкільного віку, а також дітей з відхиленням у розвитку, є технологія фізичного виховання, розроблена М. Єфименком, розвивальний ефект якої поширюється на загальний розумовий та духовний розвиток дитини. Український педагогноватор у системі фізичного виховання, яку він назвав "Театром фізичного розвитку та оздоровлення дітей”, виокремлює такі основні режими: плавальний, лежачий, повзальний, сидячий, стоячий, ходьбовий, лазальний, біговий, стрибковий. Відповідно до назв, на конкретному занятті надають перевагу основним рухам. Єфименко вважає, що у процесі фізичного виховання дітей потрібно використовувати різні заняття для хлопчиків та дівчаток, ураховуючи індивідуальні та статеві ознаки. На переконання педагога, під час занять у дітей обох статей, слід розвивати фізичні й психічні якості, які $\epsilon$ особистісними якостями чоловічості й жіночості. До таких якостей, на думку Єфименка, належать: фізичне сила, витривалість. спритність, швидкість, атлетичність, висока енергійність, наступальність, сміливість, ризиковість, рішучість, наполегливість, цілеспрямованість, сила волі, лідерство (для хлопчиків); гнучкість, точність рухів, координованість, легкість, стрункість, відчуття ритму, витонченість, лагідність, ніжність, естетичність, граціозність, компромісність, терплячість (для дівчаток) [2, 235]. Усі ці якості, певною мірою, належить виховувати у дітей обох статей - як у хлопчиків, так і дівчаток. У педагогічній технології М. Єфименка немає місця для вправ із стройової підготовки, шикування й перешикування. Натомість значна увага надається руховій активності, організації й облаштуванню ігрового простору. Адже руховоігрова діяльність сприяє засвоєнню дітьми знань про навколишній світ, його особливості й закони.

Сьогодні у багатьох освітніх закладах активно впроваджують авторську методику фізичного виховання М. Єфименка (інноваційні види фізкультурних занять: заняття-казка (за сюжетом знайомої казки); заняття 3 використанням елементів коригувальних вправ (для профілактики плоскостопості та постави); заняття-флорбол (хокей з м'ячем у залі); заняття 3 елементами силових вправ (для хлопчиків): лазіння по канату, перенесення м'яча вагою в один кілограм тощо; заняття на розвиток гнучкості, пластики, 3 елементами аеробіки (для дівчаток)

Одним із інноваційних підходів є втілення у практику роботи з фізичної культури сюжетних уроків (за методикою Н.В. Москаленко). Їх тематика - різноманітна : "Ми - діти козацького роду”, “У світі казок і пригод”, “Кругосвітня подорож”, “Подорож у Карпати”, “Альпіністи” тощо. Планування таких уроків потребує від учителя раціонального розподілу часу на вирішення освітніх, виховних, оздоровчих завдань, оскільки під час уроку учні не лише удосконалюють рухові дії, а й отримують знання 3 теми сюжету про різні явища природи, сфери діяльності людини. Для таких занять характерна відсутність механічної системи виконання рухів і рухових дій, присутня висока емоційність, вирішення проблемних ситуацій, що піднімають настрій кожного учня й сприяють активності, наполегливості, самостійності $[7,104]$. Готуючись до сюжетних уроків, учитель повинен спланувати систему власних дій організаційного та методичного характеру: підготувати інвентар та обладнання, підібрати методи організації, визначення фізичного навантаження, оцінку результатів діяльності, акцентуючи увагу на позитивних якостях досягнення учнів й задоволенні їх потреби у самоствердженні та спілкуванні.

Проведення уроків, що мають інноваційну складову, вимагають творчого, небайдужого, відповідального організатора, тобто учителя, який має не лише теоретичну й методичну підготовку, а й креативне мислення для вирішення освітніх завдань.

Висновки. Сучасна система фізичного виховання потребує активних перетворень відповідно до стандартів Нової української школи. Внаслідок запровадження нових тенденцій у галузі фізичної культури й спорту, невідкладними є розв'язання завдань, які залежать від розробки й обгрунтування інноваційних технологій, механізмів їх втілення у практику роботи загальноосвітніх шкіл, й головно, початкової ланки освіти. Інноваційний підхід до системи фізичного виховання, фізкультурно-оздоровчої роботи, що проводиться у початковій школі, вважатиметься реалізованим, якщо будуть досягнуті результати зниження показників захворюваності учнів та покращення рівня їхнього здоров'я; підвищення рівня фізичної та розумової працездатності; розвиток творчих здібностей, нахилів та задатків кожної дитини; стійка мотивація до здорового способу життя й рухової активності. 


\section{ЛІТЕРАТУРА}

1. Ващенко О. М., Єрмолова О. М., Іванова Л. І., Операйло С. І., Романенко Л. В. Фізкультурнооздоровчі заходи в режимі навчального дня молодшого школяра : Навчально-методичний посібник. Кам'янець-Подільський, 2013. 192 с.

2. Дичківська I. М. Інноваційні педагогічні технології: Навчальний посібник. Київ, 2004. 352 с.

3. Дубіна О. О. Динаміка стану репродуктивного здоров'я населення. Щорічна доповідь про стан здоров'я населення, санітарно-епідеміологічної ситуації в Україні /за ред. Шафранського В. В. Київ, 2018. 452 с.

4. Ільницька Г. С. Фізична культура. 1 клас. I семестр. Харків, 2018. 112 с. : іл., табл.

5. Державний стандарт початкової загальної освіти. URL: https://www.pedrada.com.ua/ article/ 2017.

6. Концепція Нової української щколи. URL: https://www.kmu.gov.ua/

7. Москаленко Н. В., Степанова В. І., Власюк О. О., Шиян О. В. Інноваційні технології у фізичному вихованні школярів : навч. посіб. для студ. вищ. навч. закл. Дніпропетровськ, 2011. 238 с.

8. Москаленко Н.В., Борисова, Ю.Ю., Сидорчук, Т.В., Лядська О.Ю. Інформаційні технології у фізичному вихованні : навч. посіб. Дніпропетровськ, 2014. 128 с.

9. Нова українська школа: основи Стандарту освіти. Львів, 2016. 64 с.

10. Типова освітня програма під керівництвом P. Б. Шияна. URL: https://nus.org.ua/news/

\section{REFERENCES}

1. Vashchenko, O. M. (2013). Fizkulturnoozdorovchi zakhody $v$ rezhymi navchalnoho dnia molodshoho shkoliara [Atletic-heals measures are in the mode of educational day of junior students]. Kamianets-Podilskyi, 192 p.[in Ukrainian].

2. Dychkivska, I. M. (2004). Innovatsiini pedahohichni tekhnolohii [Innovative pedagogical technologies]. Kyiv, 352 p. [in Ukrainian].

3. Dubina, O. O. (2018). Dynamika stanu reproduktyvnoho zdorovia naselennia [Dynamics of the state of reproductive health population]. Kyiv, 452 p. [in Ukrainian].

4. Ilnitska, H. S. (2018). Fizychna kultura. 1 klas. I semestr [A physical culture is a 1class]. Kharkiv, 112 p. [in Ukrainian].

5. Derzhavnyi standart pochatkovoi zahalnoi osvity [State standard of elementary school education]. Available at: https:// www.pedrada.com.ua/ article/2017. [in Ukrainian].

6. Kontseptsiia Novoi ukrainskoi shchkoly [Conception of new Ukrainian school]. Available at: https://www.kmu.gov.ua/[in Ukrainian].

7. Moskalenko, N. V. (2011). Innovatsiini tekhnolohii u fizychnomu vykhovanni shkoliariv [Innovative technologies are in physical education of school children]. Dnipropetrovsk, 238 p. [in Ukrainian].

8. Moskalenko, N.V. (2014). Informatsiini tekhnolohii u fizychnomu vykhovanni [Information are in physical education]. Dnipropetrovsk, 128 p. [in Ukrainian].

9. Nova ukrainska shkola: osnovy Standartu osvity (2016). [New Ukrainian school: basic standard of education]. Lviv, 64 p. [in Ukrainian].

10. Typova osvitnia prohrama pid kerivnytstvom R. B. Shyiana [The typical educational by Shyian R. B. is under direction]. Available at: https://nus.org.ua/ news/. [in Ukrainian].

Стаття надійшла до редакції 16.07.2019

\section{G5}

“Дюдина народжується на світ не для того, щоб зникнути безвісною пилинкою. Аюдина народжується, щоб лишити по собі слід вічний”.

Василь Сухомлинський педагог, публічист, письменник

“Самостійні думки витіқають тільки із самостійно придбаних знань".

Костянтин У шинський

украӥнський педагог

“Жавчання ніколи не вичерпує розум".

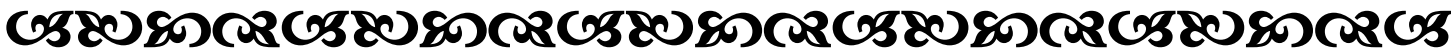

